\title{
ARHGAP32 wt Allele
}

National Cancer Institute

\section{Source}

National Cancer Institute. ARHGAP32 wt Allele. NCI Thesaurus. Code C131140.

Human ARHGAP32 wild-type allele is located in the vicinity of $11 \mathrm{q} 24.3$ and is approximately $314 \mathrm{~kb}$ in length. This allele, which encodes Rho GTPase-activating protein 32, plays a role in the modulation of both NMDA receptor signaling and small GT Pase activity. Deletion of the chromosomal region containing the gene is associated with a subset of Jacobsen syndrome patients that exhibit autism spectrum disorder. 